\title{
Pedro Penim e o Teatro Praga: A responsabilidade máxima do actor
}

\section{Mónica Guerreiro, Maria Helena Serôdio e João Carneiro}

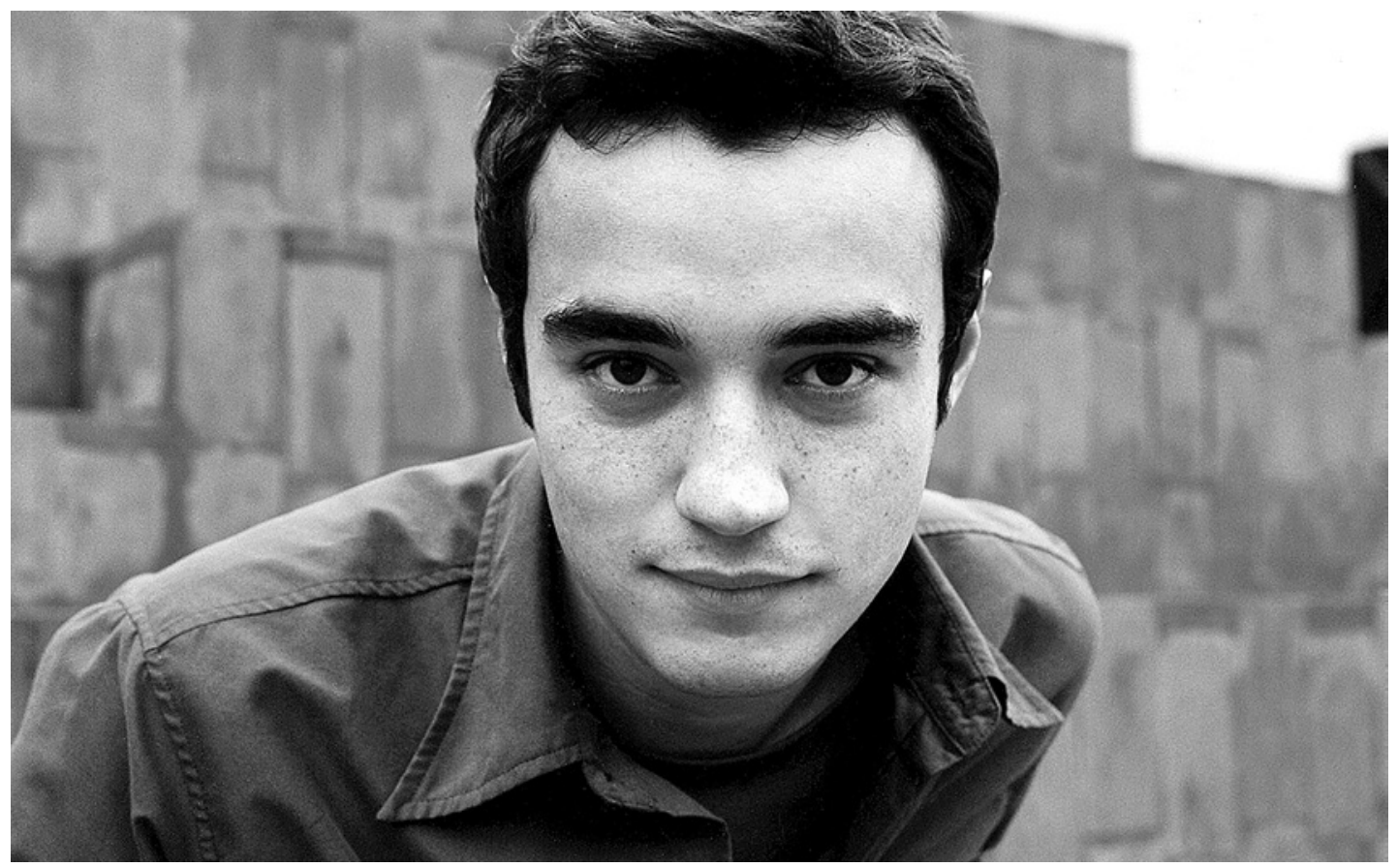

Para este primeiro número, escolhemos para conhecer Na primeira pessoa um dos mais estimulantes fazedores de teatro da nova geração: Pedro Penim. O seu trabalho, nomeadamente enquanto encenador no colectivo Teatro Praga, tem vindo a constituir-se como uma continuidade de pesquisa e de questionamento do fazer teatral para impor aos espectadores e aos próprios criadores da companhia - uma constante surpresa no que diz respeito às fórmulas, aos modelos e às convenções da representação. A entrevista foi conduzida por Mónica Guerreiro, Maria Helena Serôdio e João Carneiro.

Como se posiciona relativamente ao tecido artístico nacional, nomeadamente em termos de iniciação profissional, funções e dinâmicas de integração no meio teatral?

Considero-me acima de tudo um actor. Começo por tecer esta consideração porque a acho fundamental para entender todas as abordagens que tenho vindo a fazer ao teatro. E considerando-me actor, o meu posicionamento só faz sentido dessa forma, só pensando assim: que sou um actor. A minha formação vem toda dai e a prática acaba igualmente por reflectir isso. Falando do meu percurso: antes de entrar no Conservatório, fiz um curso com os Satyros, um grupo brasileiro que estava cá nos anos 90 . Gostava muito de teatro, tinha entretanto visto um espectáculo maravilhoso do Teatro Meridional, Ñque ou sobre piolhos e actores, do Sinisterra, e achei que era mesmo aquilo que eu queria, estar ali a fazer aquelas coisas. Foram dois os espectáculos que determinaram essa escolha: esse e 0 conto de Inverno, da Cornucópia. Este incluia no elenco muita gente saída do curso do Instituto
Franco-Português e eu fiquei com muita curiosidade em saber o que era fazer um curso de iniciação teatral, que era uma coisa que não existia. Decidi então fazer esse curso dos Satyros, o primeiro que eles deram, que era uma fantochada, [risos] mas que me ajudou a ter um primeiro confronto com fazedores de teatro (porque eu não conhecia absolutamente ninguém), e também com outras pessoas da minha geração que também lá estavam e que em comum comigo tinham essa curiosidade e esse intuito. 0 Teatro Praga formou-se logo aí, a partir de uma das turmas do curso, com algumas das pessoas que ainda hoje cá estão: a Cláudia Gaiolas, a Sofia Ferrão, a Paula Diogo... Somos só os quatro da formação original. Acho que na altura pusemos o carro à frente dos bois, porque decidimos que queríamos fazer coisas juntos e por isso precisávamos de ter uma companhia, mas isto sem qualquer perspectiva do que é que isso implicava, nem sem pensarmos muito bem no que é que íamos exactamente fazer. E foi assim: decidimos logo formar uma associação, escolhemos o nome e começámos a fazer teatro. 
Alice no armário,

Teatro Praga, 2004

(Tonán Quito),

fot. Sofia Ferrão.
Alice no armário, (Sandra Simão), fot. Sofia Ferrão.
Teatro Praga, 2004

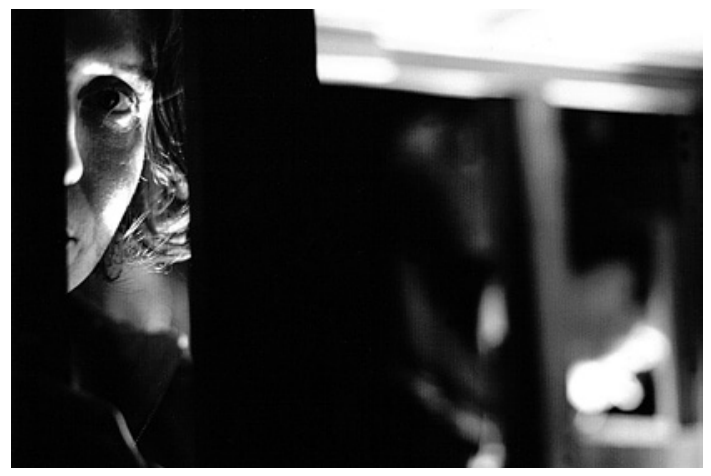

Porque é que escolheram este nome, Praga?

É que, à boleia dos Satyros, andávamos a ler muito Artaud! [risos] 0 curso começava com Stanislavsky, cada aula era um capítulo da Formação do actor. Claro que adorámos, fazia todo o sentido, eles faziam ligações com o Actors' Studio, com o cinema e a televisão, havia um certo fascínio com a interpretação do texto daquela maneira. E depois, mais tarde, apresentaram-nos o Artaud, que nos deu completamente a volta à cabeça. Quando estávamos a legalizar a associação, era a fase em que liamos muito Artaud, 0 teatro e a peste... Ficou Praga. A nossa primeira peça, que foi ainda dentro do curso, foi a partir do texto 0 concilio do amor, do Oskar Panizza, que foi uma obrigação/sugestão dos Satyros. Mas foi, para todos os efeitos, o primeiro espectáculo do Teatro Praga, no Auditório de Benfica, em Outubro de 1995. Éramos tão inconscientes que, apesar de sermos só uns alunos, enviámos textos para a imprensa, quisemos ter lá as pessoas... Também para nos apresentarmos, porque já havia essa ideia de continuidade. Depois começámos a querer fazer outras coisas. E o grupo foi-se desenvolvendo à medida de cada um de nós. Quase todos entrámos depois para o Conservatório e o grupo foi-se desenvolvendo a partir de ansiedades pessoais, crescendo com as experiências de cada membro: uns foram trabalhar com a Lúcia Sigalho, outros para a Garagem... E as opções e os rumos do grupo foram-se fazendo assim: a escolha dos textos, os actores...

0 Teatro Praga equilibra, portanto, trabalhos individuais em colaborações variadas e depois o "regresso a casa". Isso pressupõe alguma estabilidade formal, um núcleo

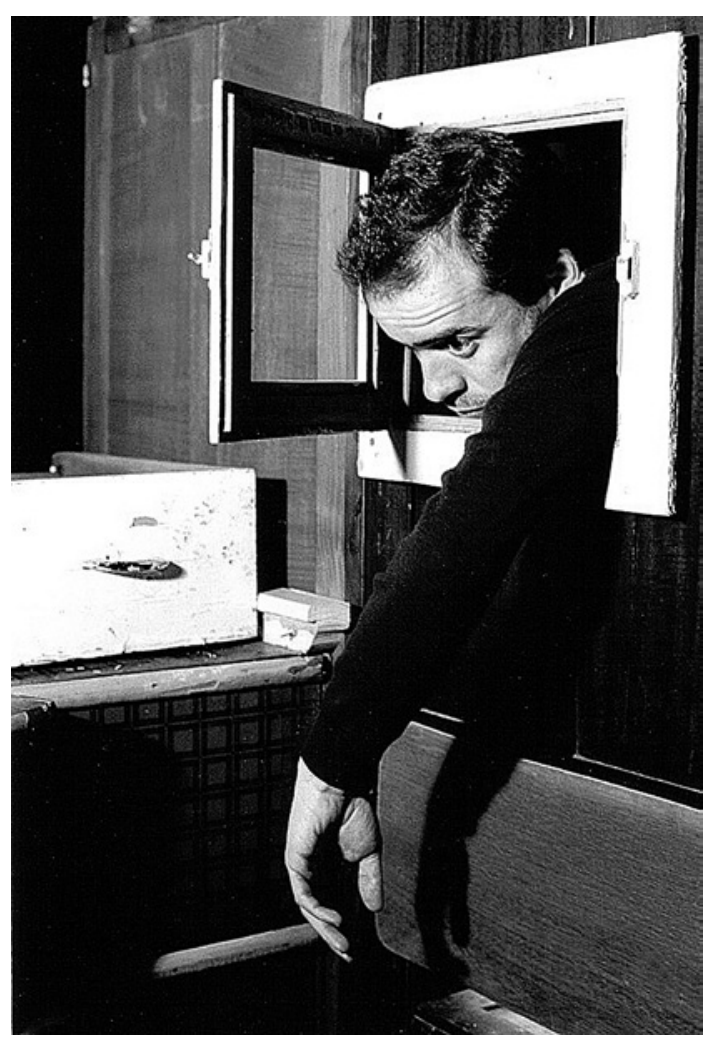

uma ideia do que queriamos fazer, queríamos fazer teatro, sem mais - houve muito essa necessidade das pessoas, na ânsia de se formarem, de irem buscar experiências fora.

E algumas pertenceram a outras companhias durante muito tempo. Só recentemente é que "fecharam o círculo" no sentido de firmar que "nós somos o Teatro Praga", somos estas dez pessoas. A formação está agora definida. Mas não há propriamente a vontade de termos um elenco fixo. Há uma estrutura de produção, que funciona em permanência, e um grupo de actores que são a direcção mas que não têm um cargo: são os pensadores.

E a entrada no Conservatório? De que forma é que alterou o projecto original ou as vossas perspectivas?

0 Conservatório, acima de tudo, formatou-nos enquanto grupo. Dá para perceber isso muito bem olhando para o nosso historial e vendo que género de peças é que faziamos antes e as que fizemos depois do Conservatório. Começámos, por exemplo, a fazer Ödön Von Horváth, que já não tem nada a ver com o Oskar Panizza ou com o Artaud. Essas absorções foram sempre muito determinantes nos nossos espectáculos. Mas o Conservatório ajudou-nos, primeiro que tudo, a encarar os pares, conhecê-los, porque a nossa única experiência tinha sido com o grupo brasileiro, que era de certo modo "marginal". De resto havia um desconhecimento absoluto relativamente à situação do teatro português, ao que nele era a ordem dominante. Conhecendo os professores, começámos a integrarnos nesse meio, porque muitos deles tinham as suas companhias: o João Mota, o Carlos J. Pessoa... E eles também nos conheceram a nós, já enquanto grupo, porque assim que entrámos no Conservatório apresentámo-nos como fazendo parte do Teatro Praga [risos]. 0 Conservatório ajudou-nos, principalmente, a perceber as regras do espaço do teatro: onde estão as pessoas, onde estão os teatros, onde está o dinheiro, quem são os autores, o que se está a fazer...

E perceber como se estrutura uma companhia. Daí surgiram 


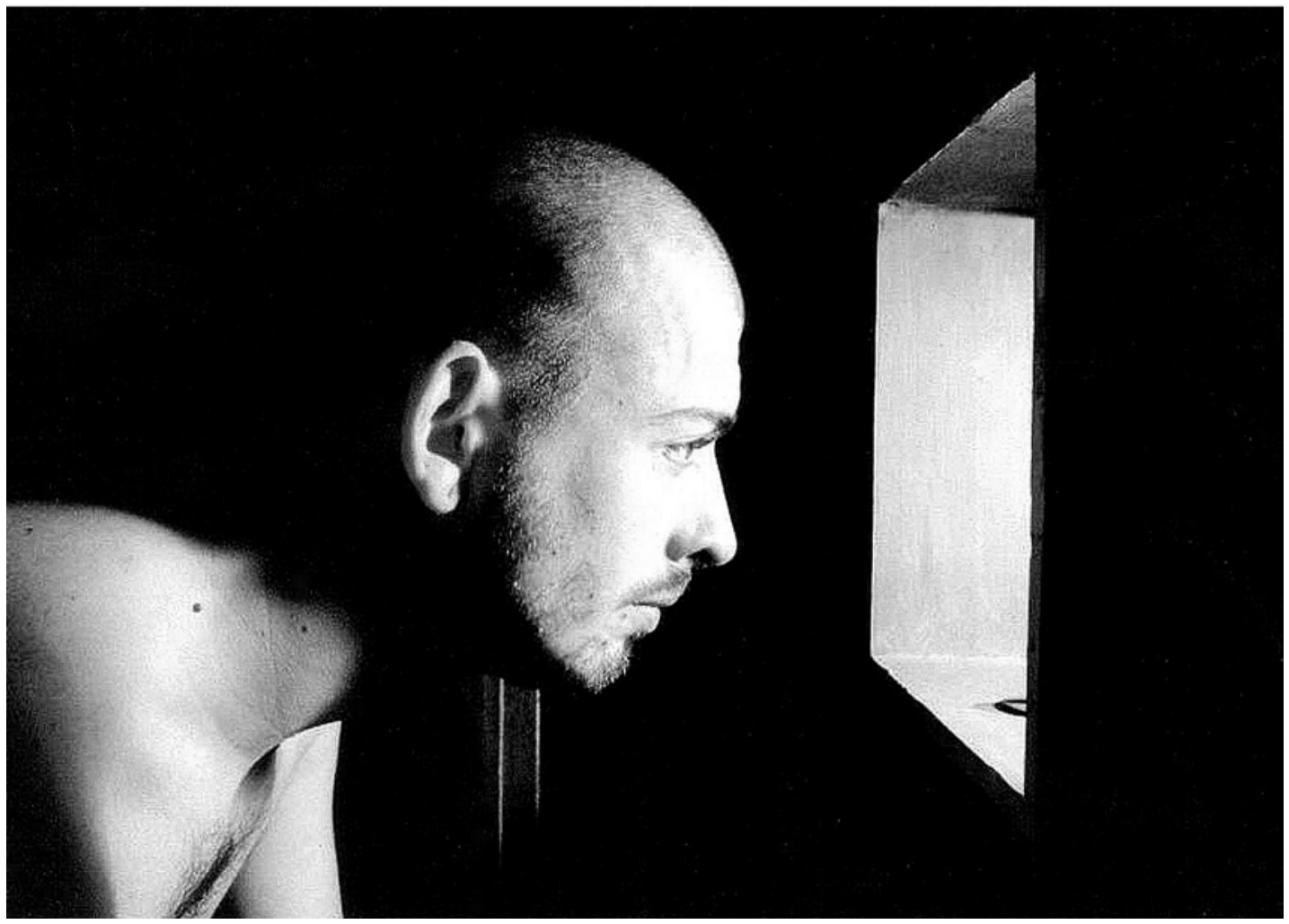

relacionamentos que nos permitiram sair e trabalhar com outros grupos, experiências que acabaram por ser determinantes nas coisas que ímos fazendo. Fomos sempre continuando, durante muito tempo sem apoios, até porque não sabíamos como isso funcionaria. Fomos aprendendo todas essas coisas mas com uma actividade sempre contínua, sempre a fazer espectáculos, ainda que sem ver uma luz ao fundo do túnel que nos fizesse querer ser como a Cornucópia ou seja quem for. Isso nunca existiu e até hoje não existe, mas houve sempre uma vontade de continuar. Fizemos pelo menos um espectáculo por ano. E os conteúdos dos espectáculos foram sendo também adaptados a essas experiências, que eram trazidas para dentro do grupo.

$E$, neste momento, tem alguma ideia sobre o tipo de teatro que gostam de fazer? Ou antes: que preferências, que linhas de contacto? Ou será que as coisas se vão desenhando à medida que trabalham?

As coisas foram sendo desenhadas de espectáculo para espectáculo. Conseguimos, nos espectáculos que fazemos, identificar algumas coisas, nomeá-las e colocá-las em sítios. Continua a não haver uma necessidade de fazer sempre desta ou daquela maneira. Não determinamos à partida o que nos interessa ou não. Para já, se não nos interessa, procuramos perceber porquê e, frequentemente, acabamos por lá ir parar. Podemos catalogar-nos como um grupo que pesquisa, e essa pesquisa incide, para já, nos actores e nas relações entre os actores e o público: há uma preocupação muito grande com a convenção, com o questionamento da convenção, o que é fazer teatro num teatro ou fora de um teatro, o que isso implica em termos de organização, pôr muitas vezes isso à mostra, a exposição de processos, etc. Tudo isso nos interessa muito. Não gosto de the chamar desconstrução porque é uma palavra muito feia, mas há a construção de um universo a partir de pequenas partes, e a formação de um todo a partir dessas partes, que são as idiossincrasias do teatro. Há um lado quase vampiresco em relação à tradição. Por isso, quando nos perguntam se 0 que fazemos é performance, dizemos que não, que o que fazemos é teatro. Continua a ser isso que queremos fazer. Há é o pressuposto de não fazermos espectáculos que já estão feitos. Aqui, neste grupo, não é o espaço para isso. Aceitamos que se faça, não recusamos nada, mas não é esse o nosso objectivo. Também na nossa geração há muitas pessoas que continuam a insistir em fazer teatro como fazem o João Mota ou o Luís Miguel Cintra. Esse à partida parece-nos um caminho a não tomar.

Quando fala em desconstrução e questionamento das convenções, é evidente que faz sentido que o Teatro Praga ocupe um espaço como o armazém do Hospital Miguel Bombarda, que não é um teatro tradicional (apesar de cá estar um palco). Os espectáculos concebidos aqui podem ser transferidos para outros locais ou, pelo contrário, consideram que o espaço condiciona o resultado, é uma moldura que constrói ela própria parte do espectáculo?

Essa pergunta é muito interessante porque os espectáculos que nós construímos aqui de raiz acabaram por se tornar muito site-specific, ou seja, há uma apropriação da morfologia do próprio espaço. Há espectáculos, como o De repente..., que foi concebido entre dois teatros, o de Torres Vedras e o de Sintra, que nos foi mais fácil transportar para espaços diferentes. Já com outros, tornou-se mesmo impossivel fazê-los fora daqui, como o Alice no armário. Foi feito para aqui, as coisas foram sendo trazidas aqui do Hospital. É que há essa preocupação de haver uma relação com o espaço hospitalar, porque é aqui que estamos e isso tem o seu peso. Acontecem as duas situações, porque cada projecto é encarado de uma forma muito específica. 0 Alice foi feito para este espaço e o espectáculo que vamos estrear em Agosto, Título, também foi construído para este espaço. 
Private Lives,

Teatro Praga, 2003

(Paula Diogo e Carlos Alves), fot. Luis Piorro.

Teatro Praga, 2003

(Patricia da Silva),

fot. Luis Piorro.
Qual é para vocês a importância de ter um espaço próprio? Para nós foi fundamental conseguirmos estar aqui², termos um espaço para ensaiar e para apresentar aquilo que quisermos, sem depender de outro sítio. Trabalhámos durante muito tempo no Teatro Taborda, que foi um sítio fundamental para alguns espectáculos que lá fizemos. A história reflecte-se nos espaços. Somos quase uma estrutura-esponja, que absorve não só as experiências, mas também os espaços e tudo o que acontece. Nós fazemos um teatro que se apoia muito no real, no real da situação teatral. Às $21 \mathrm{~h} 30$ começa. E esse pressuposto leva-nos a querer um aqui e agora. Os nossos espectáculos são muito baseados em aqui e agora. E quando nos convidam para outros sítios, há sempre essa dificuldade de perceber o aqui e agora nessas circunstâncias, porque as coisas são muito rápidas: chega num dia, monta, e faz a peça no dia a seguir. Ás vezes é bom, porque nos leva a reinventar e a actuar no momento: fazemos muitas vezes isso porque todos os dias temos um público diferente e isso também faz parte do aqui e agora. Os espectáculos fazem-se de assumir essas questões todas. Quem é que vem hoje? Vens tu! Então o espectáculo é diferente porque vens tu. Onde é que estamos, quem é que está, como é que eu hoje me estou a sentir? Estou a fazer Nöel Coward [Private Lives] e sinto-me um farrapo: como é que eu lido com isso? Isto depois leva-nos a uma outra questão, a da personagem, um tema que nos persegue [risos] e sobre o qual continuamos a falar horas a fio. Há, pelo menos, uma recusa da convenção no que diz respeito à quarta parede da personagem, imune a tudo o que a rodeia. Ao contrário disso, há uma absorção de tudo: energias, pessoas, espaços como este, como o Miguel Bombarda.

Peguemos no assunto magno que é o assunto da personagem. Como é que vocês a encaram neste momento? Ela coloca-vos alguns problemas específicos? Ou são as questões que se colocam de cada vez que se encena um espectáculo?

Essa é uma questão interminável, deparamo-nos com ela de cinco em cinco minutos em cada ensaio. É uma espécie de dogma, também. Principalmente no teatro português, há uma valorização muito grande do encarnar da personagem, da apropriação da personagem, de como a personagem não falha, uma construção contínua... Como em duas horas tu me provas que és aquela personagem. E nós sentimos esse peso, até porque a nossa formação no Conservatório vincava muito essa vertente, do actor quase camaleónico, que agora faz de padeiro e logo a seguir de príncipe da Dinamarca. Para nós, enquanto criadores, esse é um peso muito grande, pensar que nos subjugamos a essa ideia - que vem do Stanislavsky, depois desenvolvida no Método - que eu não sou eu, agora sou um outro. Nós recusamos à partida essa relação de entrega à personagem, o deixarmo-nos levar por aquilo que a personagem quer. Isso implica que há a construção de uma persona, uma persona teatral. Porque não há a pretensão de ser eu em palco: não sou eu em palco, como é óbvio. E isso, mais uma vez, é a assunção da convenção: alguém está a olhar para mim e eu estou a fazer alguma coisa.
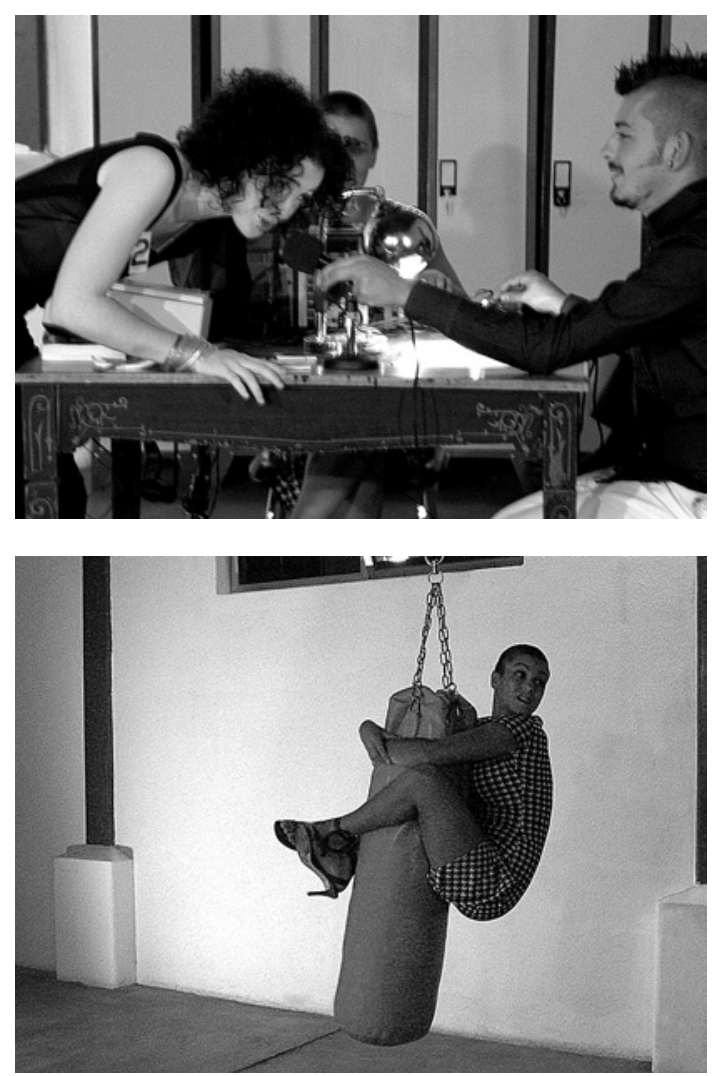

Nessa relação com o texto, com a história e com a personagem, vocês vão construindo um código algo romântico, embora isto possa parecer contraditório. Não romântico no sentido da personagem exaltada, mas no sentido do prazer que sentem ao brincar, ao criar espectáculos que lançam a noção do fantasioso, do lúdico... Ou seja: há um trabalho permanente de construção e desconstrução, uma vontade de manterem a capacidade de maravilharem. Em espectáculos como Shall We Dance ou Alice no armário, há momentos em que sentimos que a construção do espectáculo é também uma forma de acompanhar a construção de alguns ícones do cinema ou da música. A banda sonora dos vossos espectáculos é, aliás, um dos aspectos mais curiosos de apropriação de outros códigos artísticos. Aplicam, por exemplo, em momentos de silêncio uma música forte, toda ela quase sempre melodiosa e romântica, bem estruturada do ponto de vista da sua harmonia. Sendo um grupo jovem, e trabalhando de forma muito experimental, acabam contra o que seria a convenção - por trabalhar universos literários, artísticos, melódicos, que não são os que associaríamos a propostas de provocação, que se julga muitas vezes ser o que os jovens fazem. Esta noção do "jovem radical", da violência, é uma coisa que não existe nos vossos espectáculos.

Nós somos muito iconoclastas, todos, o que à partida se reflecte muito nos espectáculos. Mas acho que esse lado romântico, particularmente nesses dois espectáculos que referiu, tem muito a ver com quem os constrói. Se calhar, um outro espectáculo nosso, como o De repente..., já não é nada romântico. Já Um mês no campo desenvolvia um pouco mais o seu romantismo. Mas essa é uma das nossas questões principais: olhar para a nossa geração e perceber o que é que as pessoas andam a fazer, que música ouvem, por que sítios é que andam, o que consomem. Mas acho que esse 

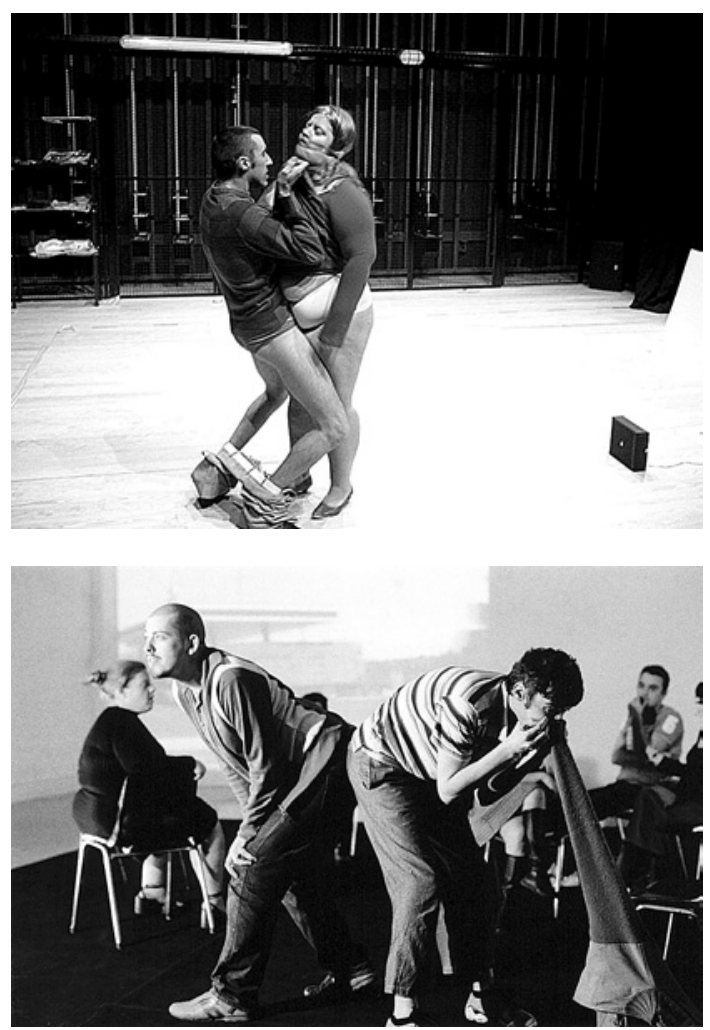

romantismo acaba também por ser o romantismo da personagem: apesar de a recusarmos, temos uma espécie de nostalgia desse lado mais claro das questões do teatro. Como essas questões eram postas, como as coisas se faziam com mais clareza. E nós não conseguimos fazê-las dessa maneira. Não está na nossa prática nem nos nossos corpos actuar dessa forma. Neste último espectáculo há uma espécie de nostalgia: propusemo-nos voltar a fazer uma personagem, e tentar perceber como é que isso funciona depois de tantos espectáculos em que andámos a dar pontapés à personagem. Mas, de qualquer maneira, não é para ninguém ver [risos], é só uma experiência. Na verdade, Título é um espectáculo que decorre em dois momentos: fazemos a Menina Júlia e ao mesmo tempo o espectáculo decorre. É a nossa Menina Júlia: da nostalgia e do Conservatório. A proposta era fazê-la como nunca a conseguimos fazer. Mas o espectáculo não é isso, o público está a ver outra coisa.

Mas tudo isso impõe que se volte a formular a questão: mais importante do que falar sobre o que significa fazer uma personagem (representá-la, desmontá-la, etc.) é a noção de que a personagem irrompe nos vossos

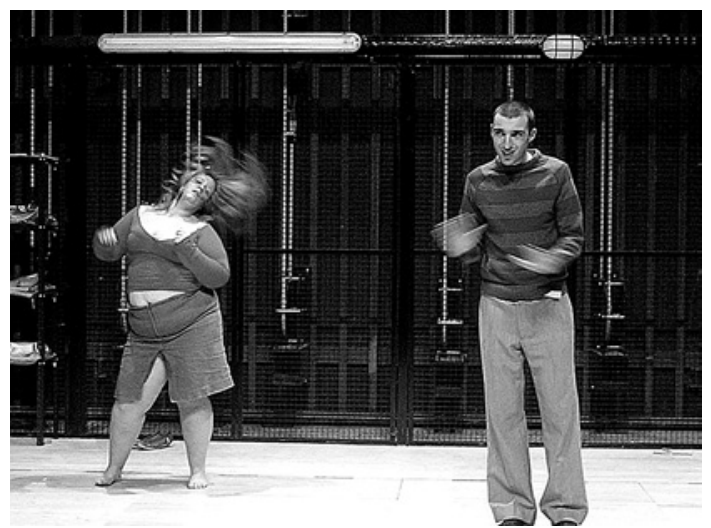

De repente...

Teatro Praga, 2003 (André Teodósio e Cláudia Jardim), fot. Pedro Penim

espectáculos de uma forma inesperada. Curiosamente, 0 discurso de desmontagem do presente tem de se confrontar com coisas que foram ditas, e que eventualmente terão sido bem ditas, por confronto com outras que não se conseguem dizer. 0 que se sente nos vossos espectáculos é que, mais do que construir personagens, há uma preocupação com os mecanismos da construção da cena, com os mecanismos de transformação e de representação. Por vezes, irrompe aí qualquer coisa parecida com uma personagem. $E$ isto é particularmente evidente em espectáculos como Private Lives, um dos mais enigmáticos. Tudo advém da situação em que nos colocamos: toda a situação é construida para que isso se possa dar em nós, para que essa dúvida se possa dar naquele momento. Tínhamos à partida a certeza de que iriamos fazer aquelas personagens, que iriamos construir aquela peça naquele momento à frente de determinado público, só não sabíamos como. Nem quem. Nem que música ou que texto é que ia entrar. Mas trata-se sempre de uma predisposição para que esse mecanismo se revele à frente de quem vem assistir ao espectáculo, sem sermos nós a imputarmo-nos essa responsabilidade: aquele já era um jogo construido para esse efeito. Esses momentos de percepção do que é que eu vou fazer e como o posso fazer - vou ser o protagonista? com quem? contigo? não, contigo? está bem! - põe-nos num estado de alerta máximo relativamente ao que faço e a quem está a ver. E depois é o questionamento permanente: que espectáculo é que se está aqui a fazer afinal? Para onde é que está a ir o espectáculo? Onde é que ele está? Para onde foi a personagem? Estou a ser? Sou o Elliot, estou a conseguir fazê-lo? Porque a peça do Nöel Coward pressupunha isso, que se fizesse realmente. Já o Turgueniev, com todas as suas questões niilistas, permitia muito mais facilmente deslocar diálogos, contextos, etc. Private Lives é uma peça de deixas cómicas, de piadas (punchlines), uma peça feita de anedotas. Colocarmo-nos
Um mês no campo Teatro Praga, 2002 (Cláudia Jardim, Carlos Alves e André Teodósio), fot. Sofia Serrão. 


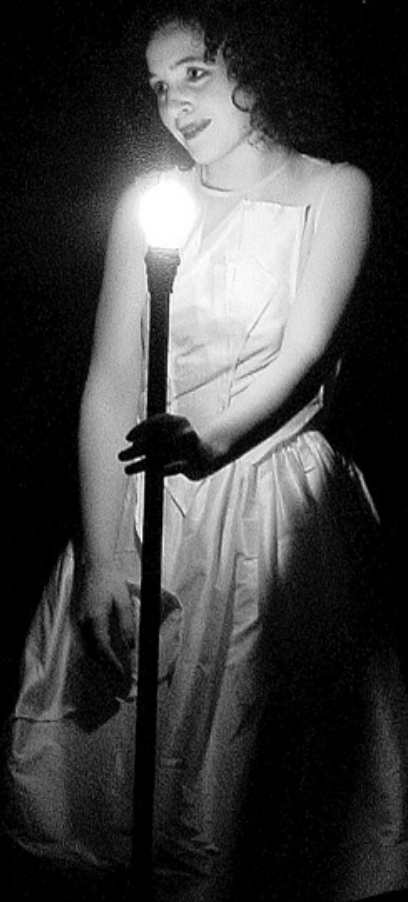

perante isso numa peça, representando personagens, era uma questão permanente. Quem é que eu sou, primeiro, e como é que foi decidido que seria assim - porque era deixado ao acaso, com o lançamento dos dados que predestinava a atribuição dos papéis. Tudo no sentido de extremar cada vez mais a visibilidade do mecanismo teatral. E nós queriamos mesmo ser a personagem, tentávamos fazer a personagem, e depois toda a concepção do espectáculo é que nos levava a questionar isso. Mas enquanto actores tentávamos salvar o espectáculo, porque esse é o mecanismo dos actores. Como já referi ao início: pela nossa formação e pelo meio em que nos inserimos, temos necessidade dessa eficácia do espectáculo.
Percebe-se nas suas palavras uma ideia clara do que querem e uma grande disponibilidade para experimentar relações, formas de construção, etc. Têm algum referente estético - nacional ou internacional - que possa ser um parâmetro ou um ponto de ancoragem das vossas experiências?

Pessoalmente, sim, mas enquanto grupo não consigo avaliar, não tenho essa perspectiva. Trabalhei com um grupo belga, o Tg. STAN, que não são propriamente originais, porque seguem uma tradição da Flandres e dos Países Baixos de uma nova apropriação do texto, de uma outra relação entre os actores, o texto e o público. 0 grupo começou com um encenador que veio agora há pouco tempo à Culturgest, 0 

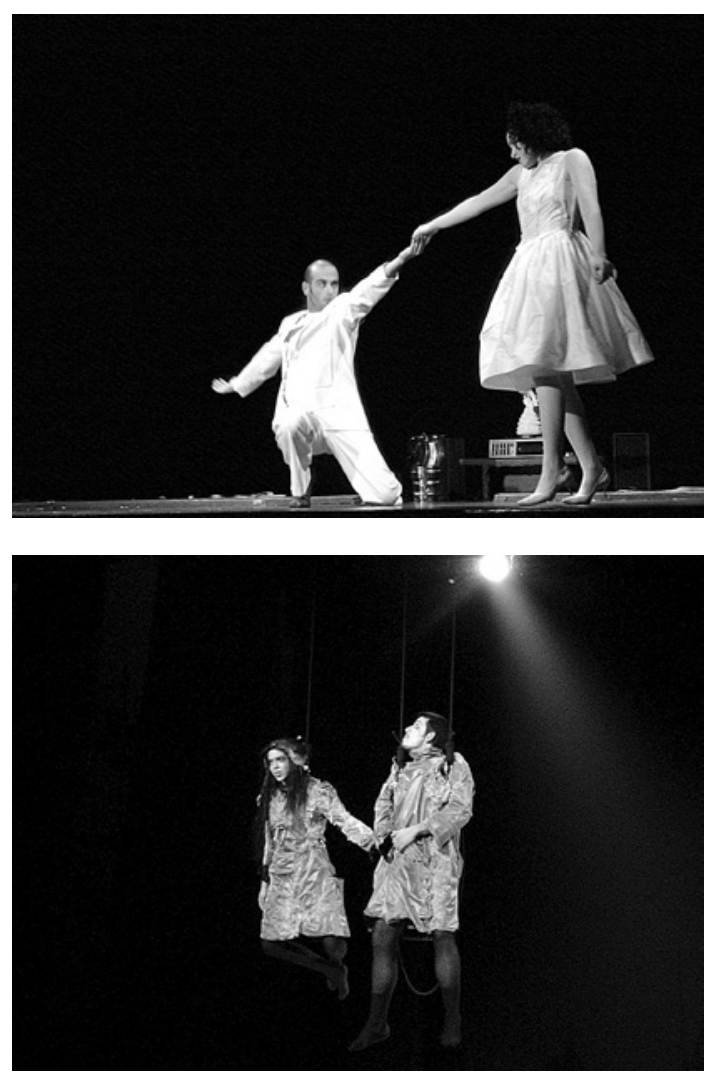

Josse de Pauw, que foi o mestre de alguns dos actores do STAN. Para mim, a experiência com os STAN foi o meu verdadeiro Conservatório. Digo isto sem recusar a formação académica que o Conservatório me deu, a qual hoje em dia consigo até apreciar melhor, ao ponto de reconhecer os ensinamentos valiosos de professores de quem eu até nem gostava nada - actores donos de uma sabedoria que tinha muito a ver com a convenção, que detinham a referência máxima em relação ao mecanismo do Método. Alguns grupos independentes recusam isto e apostam mais nas emoções e como é que elas produzem espectáculos. Mas esse lado racional da construção de um espectáculo - que depois nós questionamos - está muito reflectida nos ensinamentos de alguns actores que foram meus professores. Mas os STAN têm também essa referência de um teatro clássico belga, porque Portugal e a Bélgica têm isso em comum: não têm um teatro baseado numa tradição muito pesada, como acontece com Espanha, Inglaterra ou França, onde em qualquer altura do ano se pode ir ver uma peça na Comédie Française. Nós não temos essa grande referência institucional, não temos uma Royal Shakespeare Company, e os belgas também não, porque o nosso teatro sempre foi feito a partir de importação de modelos. Mas os belgas conseguiram tornar isso numa mais-valia que é hoje uma marca com grande visibilidade no tecido cultural europeu. 0 teatro holandês e da Flandres é o que está agora na moda, digamos assim. Participei num espectáculo que se chamava Point Blank, a partir de Platonov, do Tchekov, representado em vários pontos da Europa. E, isso sim, foi um Conservatório. Porque me obrigou a questionar enquanto artista, coisa que o Conservatório em Lisboa não faz. Pensa nos actores como executantes, bons e virtuosos executantes, às mãos de um encenador. E no STAN há uma responsabilização máxima dos actores por aquilo que acontece. Isso é também uma marca do Teatro Praga: os actores responsabilizam-se pelas coisas porque eles são os criadores do espectáculo. São os actores que estão em cena, é uma questão do aqui e do agora. 0 facto de trabalharmos frequentemente sem encenador é coerente com isto. Não tenho desculpas, nem ninguém a quem apontar responsabilidade pelo meu trabalho - a nivel conceptual e a nível prático.

Como é que, então, funciona um colectivo de actores que, como há pouco o Pedro dizia, são os "pensadores", portanto, "os criadores" dos espectáculos? Porquê continuarem a denominar-se actores? $0 u$ antes: qual é o vosso entendimento das atribuições do actor?

Há esse entendimento do actor como alguém cuja imagem - e voz, e criatividade - vai ser usada ao serviço de alguma coisa. Isso sempre me perturbou, essa ideia do actor que está pronto para fazer qualquer coisa, a qualquer momento, seja por quem for. Chama-te o Filipe La Féria e tu vais, e chamate o Luis Miguel Cintra e tu também vais. Essa é uma atitude que me parece denegrir o actor enquanto pessoa, enquanto criador e enquanto artista. É aquilo a que chamamos o actorbarro. Eu próprio fiz coisas muito diferentes do que faço no Teatro Praga: Luzes, Pêssegos, e agora recentemente um outro espectáculo também no Teatro Aberto, Paisagens americanas. Mas nós não queremos ser actores-barro. E é a partir desse princípio que o espaço é aberto para toda a gente poder intervir da maneira que quiser, não só nas decisões do grupo, mas também em cada espectáculo. É por isso também que há fases em que o caos se instala, também porque somos pessoas muito diferentes, com vontades diferentes: os espectáculos fazem-se de compromissos mediante as ideias de quem faz a proposta e as questões levantadas por todos os outros. Há todo um processo de convencimento que nos obriga a pensar muito sobre aquilo que estamos a propor: não posso só querer uma parede cor-de-rosa, tenho de articular essa necessidade, justificá-la. As minhas ideias como encenador - porque no fundo somos todos co-encenadores - têm de ser muito mais honestas, porque têm de fazer sentido para toda a gente. E muito mais responsáveis, porque os actores não são formados para isso: são formados para serem veículos de um espectáculo, não para responderem por ele.

Nesse sentido, como é que se determina a distribuição de funções dentro do grupo, ou a escolha da programação? 0 Pedro por vezes é encenador, mas frequentemente é actor, assina a concepção geral, o projecto, a dramaturgia, a versão ...

A tendência agora, no Praga, é abolir definitivamente a figura do encenador, porque é uma coisa que nos oprime. Num dos nossos últimos espectáculos com encenador, o De repente..., 


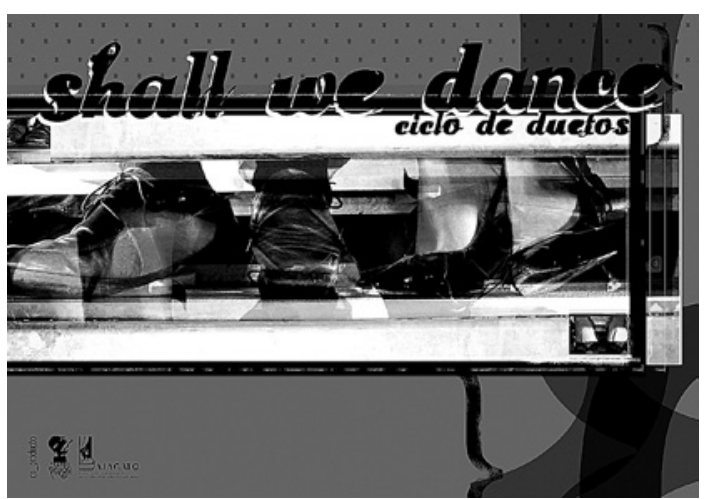

assinei a encenação porque fui eu que fiz a adaptação do texto do Nuno Bragança, e por isso a peça já estava muito formatada àquilo que eu tinha apreendido do romance. Pareceu-me justo assumir uma posição mais de espectador relativamente ao que se estava a fazer, até porque não entrava na peça. E também era uma co-produção com outra companhia, o Teatro de Sintra, o que exigia outro tipo de organização. Mas as escolhas dos espectáculos podem acontecer de várias formas: por sugestão minha ou de outra pessoa. 0 Private Lives começou quando li a peça e logo me ocorreu o jogo de distribuição de personagens ao acaso. Delineei uma equação que depois foi desenvolvida no grupo. No caso da Alice no armário, a Paula Diogo participou num evento do António Catalano, os Armários sensíveis, que teve lugar no âmbito do projecto Percursos, e a partir dai propôsnos fazer uma apropriação desse universo dos armários com o texto da Alice no país das maravilhas, do Lewis Carroll. Às vezes são estas equações, outras vezes não, são questões muito práticas como: queremos fazer um texto russo.

\section{Já que referiu uma co-produção com uma outra} companhia, gostaria de lhe perguntar como é que avalia essas colaborações e se o Teatro Praga está disponível para outras co-produções.

Interessa-nos muito colaborar com outros grupos e temos agendada uma co-produção mais para o final do ano com o Cão Solteiro. Este último espectáculo que estreámos foi uma colaboração com dois artistas plásticos, a Catarina Campino e o espanhol Javier Nuñez Gasco. Interessa-nos muito esse lado da colaboração porque isso baralha-nos, e o facto de nos trazer questões é muito estimulante. Fazer um espectáculo com um grupo como a Companhia de Teatro de Sintra ou com uma artista como a Catarina Campino baralha-nos em sentidos diferentes, e interessa-nos procurar as mais-valias nesses criadores. Nós temos claramente muita vontade de abrir cada vez mais horizontes. E isso pode implicar contar com companhias cujos percursos nos interessem e em que nós vejamos claras semelhanças com o nosso, ou dúvidas parecidas mas práticas diferentes, como é o caso do Cão Solteiro, que têm a mesma espécie de ansiedades em relação à cena, mas em que depois a concretização é quase diametralmente oposta. Ou então companhias como a Casa Conveniente, com quem temos muitas afinidades e com quem também faremos, em princípio, um espectáculo em 2006. Os nossos planos para o futuro implicam uma grande aposta nas co-criações, e na tentativa de chamar mais pessoas exteriores à estrutura. 0 projecto Shall We Dance é para continuar: um formato em que uma pessoa do Teatro Praga convida uma pessoa de fora para fazerem um espectáculo em conjunto.

\section{Já conseguem avaliar se têm um público vosso?} Não... Aqui no Miguel Bombarda começamos a conhecer algumas caras de pessoas que vêm cá. Se calhar é o público dos espectáculos do Teatro Praga, mas não fazemos essa avaliação. Como gostamos muito de fazer espectáculos fora de Lisboa, não pensamos se as pessoas são de cá ou se vêm de fora. 0 Shall We Dance foi concebido fora e com essa vocação de poder viajar, e também o Private Lives tinha esse intuito... Mas há diferenças, claras, na maneira como nos recebem em Lisboa e como nos recebem em Viseu. Em Viseu, com Um mês no campo, tivemos uma experiência alucinante... Porque é um texto clássico, e as pessoas esperam coisas dos textos clássicos. E nós tratamo-lo de uma forma que está muito apoiada na relação que eu estabeleço contigo agora em cena, "para onde é que isto vai?", não há marcações, nunca houve ensaios de palco para determinar marcações... Foi tudo improvisado a partir do momento em que sabiamos o texto de cor. E em Viseu sentimos um espécie de embate, em que as pessoas se perguntavam que objecto era aquele, o que é que se estava a fazer com estas palavras, se aquilo era um ensaio... Ouviu-se esse tipo de comentários, que eu percebo, e até começámos a integrar essas reacções no texto, "mas não há figurinos, não há cenário!", porque o conceito o permitia. E esse comentar do acontecimento é uma espécie de prova de que aquilo está a acontecer ali na realidade, não é uma viagem no tempo, estamos ali e naquele momento. 0 facto de isso ser visto como um ensaio é a tal exposição do processo. E as pessoas têm direito a não querer ver ensaios, isso é legítimo. Se a única informação que as pessoas têm é: Um mês no campo, de Turgueniev, pelo Teatro Praga... Ainda por cima pensarão logo que vêm cá uns checos fazer a coisa "à séria" [risos]! Mediante essa informação, aquilo que nós fazemos pode ser encarado como um logro, realmente. Fazer aquela peça é seguir o texto, fazer o que as didascálias pedem, seguir as indicações do autor, ter figurinos de época. E tudo isso é subvertido. Nessas ocasiões tenho sempre vontade de devolver o dinheiro a essas pessoas. É por isso que no Título damos a escolher às pessoas: ou pagam ou não pagam. Resolvemos aí uma série de questões éticas [risos]. E aos que não pagam permitimo-nos considerá-los colaboradores activos do espectáculo...

Já que voltou a falar deste último espectáculo, parece existir nele uma confirmação assumida de uma prática constante no vosso trabalho: em cada espectáculo há sempre dois espectáculos, aquele que contempla o trabalho interno e aquele que é lançado para fora. Esta quase esquizofrenia é produtiva?

Em Título, a questão de estarmos a fazer a Menina Júlia é produto da concepção geral do espectáculo: parte das ideias 


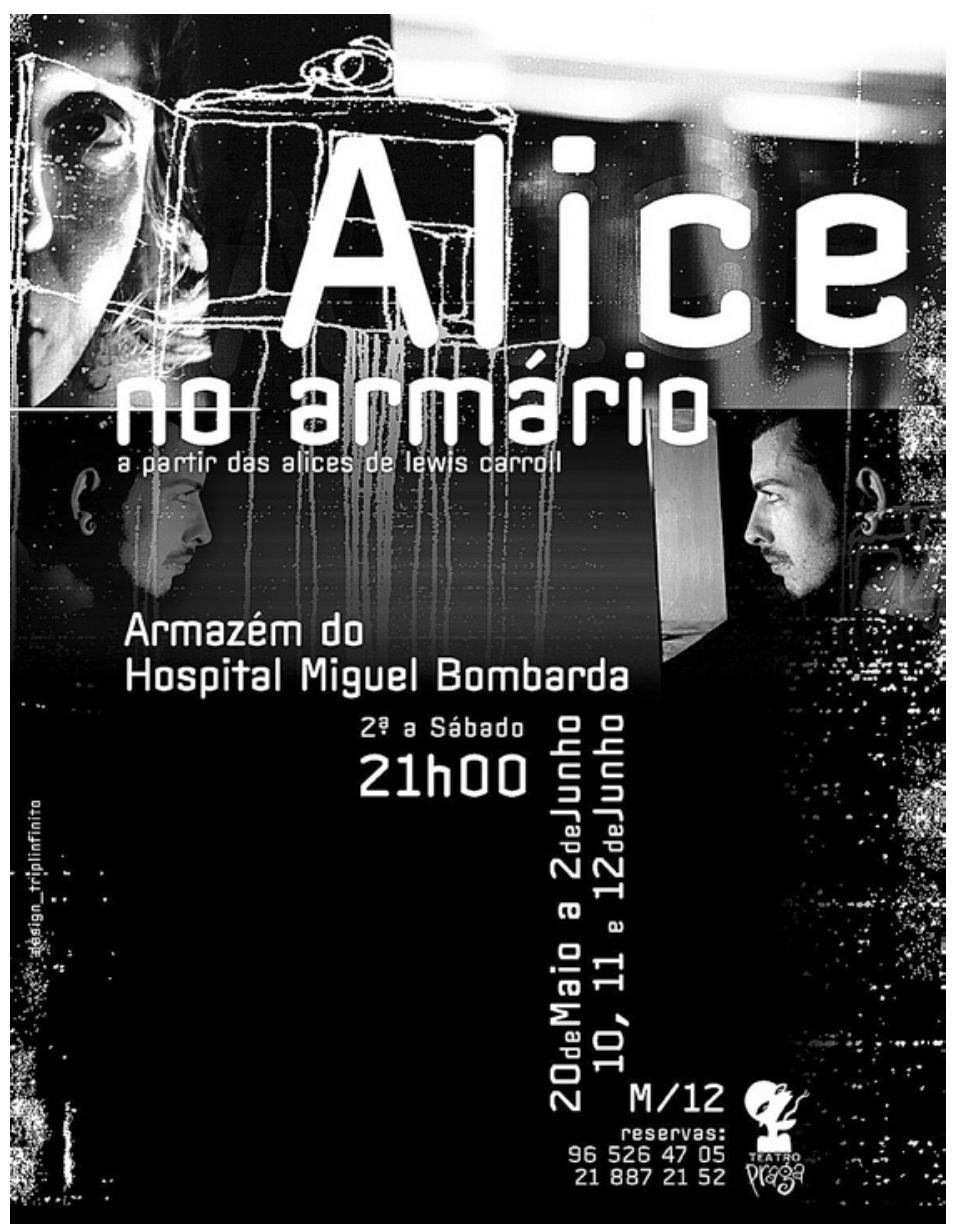

e das discussões com que o espectáculo se foi fazendo. Não há propriamente uma separação entre o que nós fazemos nos ensaios e a forma como as coisas são apresentadas. 0 que há é uma vontade grande de nos pormos em risco e em questão, isso sim. Vontade de nos questionarmos e de nos expormos, também, porque consideramos que o teatro é a arte da exposição, da exposição do eu. Recusar isso está fora de questão. Há essa assunção de que eu estou aqui para me expor, efectivamente. Não é quem me veio ver que se vai expor - a não ser que não pague bilhete, claro... [risos]. Mas temos essa consciência: se eu sou actor, é para estar no palco e assumir riscos, sim. E podemos extremar esses riscos. Muitas vezes saíamos do Private Lives muito chateados, porque como éramos postos em causa nas nossas faculdades enquanto actores, sentíamo-nos quase como participantes do Survivor do teatro: "o que vai acontecer mais?". É que entravam músicas e textos aleatoriamente, cujo objectivo era quebrar a continuidade, para que se não pensasse que aquilo que estávamos a fazer era representar a peça do Nöel Coward. Porque o espectáculo não era a peça, apesar de a estarmos a fazer. Para nós, enquanto actores, isso era muito frustrante: porque não éramos eficazes, não conseguiamos ser virtuosos; mas não havia como sê-lo, com as armadilhas que nos tínhamos posto...

Pedro Penim (n. Lisboa, 1975)

Teatro Praga (1995-)

\section{Produções:}

O concilio do amor (1995), Como se fosse esse amor (1996), Don Juan volta da guerra (1997), Spanksgiving Day (1997), 0 canto do noitibó (1998), 0 desejo agarrado pelo rabo (1999), Madame de Sade (2000), Diotima (2001), Escola de bufões (2001), La ronde (2002), Um mês no campo (2002), Private Lives (2003), Profundo Delay (2003), De repente... (2003), Shall We Dance (2003), Alice no armário (2004), Título (2004). 